\title{
EVALUASI KOMUNIKASI PUBLIK KOMISI PEMILIHAN UMUM MELALUI MEDIA SOSIAL PADA PEMILU SERENTAK 2019
}

\author{
Dila Novita, Elvira Suryani, Amanda Morlian, Mita Widyastuti, Fadhilah \\ Universitas Islam ‘ 45
}

Corresponding Author, email: dilanovitapasca@gmail.com

\begin{abstract}
Abstrak
Media sosial membentuk jaringan isu dan berbagi ide, masyarakat kemudian menjadikan media sosial sebagai media informasi kritis yang menjadi basis preferensi dalam menentukan sikap politik mereka. Inilah peluang positif bagi Komisi Pemilihan Umum (KPU) Kota Bekasi untuk memberikan informasi terkini dan terpercaya tentang Pemilu 2019. Penelitian ini menguraikan lebih lanjut tentang Strategi Pengelolaan Media Sosial KPU Kota Bekasi dalam Menyebarluaskan Informasi Pemilu 2019. Penelitian ini menerapkan paradigma konstruktivisme dengan metode penelitian kualitatif. Cara memperoleh data melalui Wawancara Mendalam dengan tiga orang Komisioner KPU Kota Bekasi. Penentuan informan secara purposive sampling. Analisis data menerapkan Koding atas jawaban semua informan. Temuan Penelitian menggambarkan bahwa pengelolaan media sosial khususnya Facebook belum dilakukan secara maksimal. Hal tersebut terjadi karena keterbatasan Pengetahuan Dalam Mengelola Media Sosial, Keterbatasan Sumber Daya Manusia, dan Keterbatasan Sumber Anggaran yang dialokasikan baik oleh Pemerintah Pusat melalui KPU Republik Indonesia maupun Pemerintah Daerah Kota Bekasi. Fakta tersebut mengindikasikan bahwa media sosial belum dianggap sebagai media komunikasi yang strategis untuk dimanfaatkan selama Pemilihan Umum 2019 di Kota Bekasi. Penelitian ini diharapkan dapat memberikan gambaran tentang praktik pengelolaan media sosial oleh institusi publik, khususnya KPU Kota Bekasi.
\end{abstract}

Kata kunci: Media Sosial; Pemilu 2019; Strategi Komunikasi

\section{Abstract}

Social media forms a network of issues and share ideas, the community then makes social media a critical information medium which becomes the basis of preferences in determining their political attitudes. This is a positive opportunity for the Bekasi City Election Commission to provide updated and reliable information to get a thorough understanding of the 2019 Election. This study further describes the Social Media Management Strategy of the Bekasi City KPU in Disseminating Information on the 2019 Election. This applies the constructivism paradigm with qualitative research methods. How to obtain data through in-depth interviews with three KPU commissioners in Bekasi City. Determination of informants by purposive sampling. Data analysis used coding on the answers of all informants. The results illustrate that social media management, especially Facebook, has not been implemented optimally. This occurs due to limited knowledge in managing social media, limited human resources, and limited budget resources allocated by the central government through the Indonesian Election Commission and the Regional Government of Bekasi City. This fact shows that social media has not been considered a strategic communication medium to be used in the 2019 Election in Bekasi City. This research is expected to provide an overview of the practice of social media management by public institutions, especially the General Election Commission Bekasi city.

Keywords: Communication Strategy; General Election 2019; Social Media 
Jurnal Administrasi Negara

ISSN : 2598-4039 (Online)

ISSN : 2302-2231 (Print)
Dila Novita, Elvira Suryani, Amanda

Morlian, Mita Widyastuti, Fadhilah

Universitas Islam '45

\section{PENDAHULUAN}

Model pemilihan umum langsung telah memberikan dampak positif bagi regenerasi kepemimpinan bangsa baik di tingkat nasional maupun daerah. Namun, di sisi lain, partisipasi masyarakat menjadi bagian sangat penting dalam keberhasilan hajat demokrasi ini setiap lima tahun sekali (Solikhin, 2017). Pemilihan umum yang dilaksanakan secara terpisah sebagaimana yang dilaksanakan sebelum pemilu 2019 dinilai kurang mendukung pelaksanaan demokrasi yang efektif dan efisien (Simamora, 2014).

$$
\text { Evaluasi tidak hanya }
$$

menyoroti tentang perbedaan waktu, namun juga besarnya biaya yang dialokasikan, dan tenaga yang dibutuhkan oleh penyelenggara pemilu (Ansori, 2017). Realitas seperti itu memicu masyarakat sipil yang tergabung dalam Koalisi Masyarakat Sipil untuk Pemilu serentak mengajukan uji materi terhadap Undang-Undang Nomor 42 Tahun 2008 tentang Pemilihan Umum Presiden dan Wakil Presiden serta Pemilihan anggota legislatif secara terpisah yang kemudian dikabulkan oleh Mahkamah Konstitusi (MK) pada 23 Januari 2014 (Asy'ari, Hilipito, \& Ali, 2013).

Ketetapan MK tersebut berdampak pada perubahan sistem pemilu dan kinerja penyelenggara pemilu, khususnya Komisi Pemilihan
Umum (KPU). Sistem penyelenggaraan pemilu yang baru menyebabkan penyelenggara pemilu mesti menerapkan cara-cara sosialisasi yang lebih massif dan komprehensif (Nuryanti, 2016). Strategi komunikasi darat melalui tatap muka langsung maupun komunikasi udara melalui media sosial harus bisa dijalankan secara sinergis (Setiadi, 2016).

Menurut riset perusahaan media We Are Social terdapat 150 juta pengguna media sosial di Indonesia. Jumlah itu naik 20 juta pengguna dibanding hasil riset pada 2018 (Setiadi, 2016). Masih sama seperti tahun lalu, Facebook menjadi aplikasi media sosial yang paling banyak digemari di Indonesia, dengan penetrasi 81 persen. Selanjutnya diikuti oleh Instagram, Twitter, Snapchat, dan LinkedIn (Pribadi, Pratiwi \& Brotowidagdo, 2019).

Gambaran di atas memberikan peluang positif yang bisa dimanfaatkan institusi publik khususnya KPU untuk berinteraksi dan menyebarkan informasi lebih massif dan efektif melalui media sosial. Hal ini dikarenakan media sosial menampilkan proses penyampaian pesan secara langsung, egaliter, dan dialogis daripada media konvensional. Dalam penelitian ini media sosial yang menjadi fokus penelitian adalah Facebook KPU Kota Bekasi. 
Jurnal Administrasi Negara

ISSN : 2598-4039 (Online)

ISSN : 2302-2231 (Print)
Dila Novita, Elvira Suryani, Amanda

Morlian, Mita Widyastuti, Fadhilah

Universitas Islam '45
Penelitian ini menjadi sangat penting dalam upaya menganalisis pengelolaan informasi yang dilakukan KPU melalui pemanfaatan media sosial khususnya Facebook sepanjang persiapan sampai setelah penyelenggaraan Pemilu 2019. Secara akademik penelitian ini akan bermanfaat dalam menambah literatur tentang pemilihan umum maupun media sosial dan khususnya akan memberikan perspektif yang lebih luas tentang pentingnya institusi publik memanfaatkan media sosial dalam berkomunikasi dengan netizen di era tuntutan keterbukaan informasi publik saat ini.

Dalam beberapa literatur belum banyak yang melakukan penelitian tentang bagaimana KPU sebagai ujung tombak sosialisasi pemilu memanfaatkan media sosial untuk menyebarkan informasi dan menjaring minat para pemilih berpartisipasi aktif di dalam pemilu. Selain itu, masih terbatas literatur yang membahas tentang bagaimana pengelolaan media sosial yang dijalankan oleh KPU dalam menanggapi berbagai saran, masukan, dan kritik yang disampaikan oleh netizen melalui media sosial mereka.

Di sinilah peluang positif bagi KPU dalam memberikan informasi yang update dan terpercaya kepada para netizen, termasuk juga sebagai strategi membangun komunikasi agar calon pemilih memperoleh pemahaman yang komprehensif tentang Pemilu 2019. Studi ini akan mengelaborasi lebih lanjut Pengelolaan Media Sosial Facebook Komisi Pemilihan Umum Kota Bekasi dalam Menyosialisasikan Informasi Pemilu 2019.

\section{Tugas Komisi Pemilihan Umum}

Ketentuan yang melahirkan Komisi Pemilihan Umum (KPU) terdapat dalam pasal 22E Undangundang Dasar Negara Republik Indonesia tahun 1945 dalam bab VII B pemilihan umum yang merupakan hasil perubahan ketiga tahun 2001. Pasal 22E ayat (5) menyatakan bahwa, pemilihan umum diselenggarakan oleh suatu komisi pemilihan umum yang bersifat nasional, tetap dan mandiri. Dalam hal ini, nama komisi pemilihan umum belum menunjukkan nama yang pasti, namun hal ini menjadi dasar bahwa pemerintah terlepas dari KPU yang bertugas menyelenggarakan Pemilu sebagai organ yang mandiri di dalam kinerjanya (Rahman, dkk., 2017).

Komisi Pemilihan Umum sebagai lembaga independen dalam sistem ketatanegaraan Indonesia disebutkan dalam Undang-Undang Nomor 17 Tahun 2017 Tentang Pemilihan Umum, Pasal 1 No. 7. Penyelenggara Pemilu adalah lembaga yang menyelenggarakan Pemilu yang terdiri atas Komisi Pemilihan Umum, 
Jurnal Administrasi Negara

ISSN : 2598-4039 (Online)

ISSN : 2302-2231 (Print)
Dila Novita, Elvira Suryani, Amanda

Morlian, Mita Widyastuti, Fadhilah

Universitas Islam ‘ 45
Badan Pengawas Pemilu, dan Dewan Kehormatan Penyelenggara Pemilu sebagai satu kesatuan fungsi Penyelenggaraan Pemilu untuk memilih anggota Dewan Perwakilan Rakyat, anggota Dewan Perwakilan Daerah, Presiden dan Wakil Presiden, dan untuk memilih anggota Dewan Perwakilan Rakyat Daerah secara langsung oleh rakyat (PKPU, 2019).

Pemilihan Umum adalah salah satu instrumen mewujudkan kedaulatan rakyat yang bermaksud membentuk pemerintahan yang sah serta sarana mengartikulasi aspirasi dan kepentingan rakyat. Pilpres 2019 menjadi bagian dari pemilihan umum serentak pertama di Indonesia dalam sejarah. Selain memilih Presiden dan Wakil Presiden, Pemilu 2019 juga menjadi momen bagi rakyat Indonesia untuk memilih anggota DPR, DPD, DPRD Provinsi, dan DPRD Kabupaten/Kota.

Pemilu serentak semula dianggap lebih efisien, baik dari sisi waktu juga anggaran dana. Menurut MK, dengan pemilu serentak, uang negara yang berasal dari pembayar pajak dan hasil sumber daya alam serta sumber daya ekonomi, dapat lebih dihemat dalam pembiayaannya. Pemilu serentak dapat pula mengurangi pemborosan waktu dan menekan konflik atau gesekan horizontal di masyarakat pada masamasa pemilu (Prasetyoningsih, 2014).

\section{Media Sosial Sebagai Alat Komunikasi}

Saat ini media sosial berdiri sebagai alat telekomunikasi komprehensif dengan karakteristik revolusionernya menawarkan konten yang dibuat pengguna, interaktif, cepat dan murah selama dua dekade (Genc, Merve \& Burcu, 2015). Lebih lanjut Schreck dan Keim (2013) menyatakan media sosial mencakup semua format media tempat kelompok pengguna berinteraksi untuk menghasilkan, berbagi, dan menambah informasi dalam proses yang didistribusikan, jaringan, dan paralel.

Dengan demikian media sosial telah menjadi bagian yang tak terpisahkan dari strategi dan praktik organisasi (Peters, 2013). Peningkatan penggunaan media sosial ini menawarkan peluang, terutama dalam hal menjangkau target (Meredith, 2012). Beberapa jenis media sosial dianggap sebagai platform yang masuk akal untuk menyebarkan informasi instan kepada audiens (Osatuyi, 2013).

Berbeda dari mode komunikasi konvensional, Media sosial dilihat sebagai "perpanjangan alami" dari lingkungan komunikasi (Papasolomou \& Melanthiou, 2012), telah menghasilkan perubahan besar dari media tradisional (Miller \& Lammas, 2010). Sifat media sosial ini telah membuatnya mudah bagi masyarakat untuk berinteraksi (Deighton \& 
Jurnal Administrasi Negara

ISSN : 2598-4039 (Online)

ISSN : 2302-2231 (Print)
Dila Novita, Elvira Suryani, Amanda

Morlian, Mita Widyastuti, Fadhilah

Universitas Islam '45
Kornfeld, 2009). Dengan penggunaan media sosial yang diperluas, organisasi tidak lagi terbatas pada komunikasi satu arah melainkan mereka dapat membangun hubungan yang jauh lebih interaktif.

\section{Pentingnya Peran Media Sosial bagi Humas Institusi Publik}

Ron Jones (2009) menjelaskan bahwa media sosial merupakan kategori media online dimana orangorang berbicara, berpartisipasi, berbagi, berjejaring dan ditandai dengan aktivitas online. Sebagian besar media sosial mendorong pengguna untuk berdiskusi, memberikan umpan balik, voting, komentar dan berbagi informasi sesuai dengan minatnya masing-masing. Masih menurut Jones, media sosial lebih dari sekedar percakapan dua arah, lebih dari broadcast satu arah seperti media tradisional, media sosial memiliki keunikan yaitu dengan adanya ide tetap terhubung dengan site, sumber dan orang-orang lainnya.

Media sosial telah terbukti menjadi media penyebaran informasi yang cukup efektif bagi banyak kalangan. Tidak jarang akibat cepatnya penetrasi informasi di media sosial sebuah isu yang belum jelas kebenarannya bergerak liar di luar kendali pihak-pihak yang terkait. Dalam kondisi seperti ini, Humas Institusi Publik dituntut untuk memiliki kemampuan mengelola media sosial agar informasi-informasi yang berkaitan dengan lembaga penaung dapat tersampaikan dengan baik. Selain itu, Humas juga harus mampu mengelola berbagai sumber informasi dan saluran komunikasi secara efektif, agar informasi yang seharusnya diketahui oleh masyarakat dapat sampai kepada publik dengan tepat (Adelia, 2019).

Penelitian ini mengacu pada teori Pemanfaatan Media Sosial Untuk Kegiatan Kehumasan (Jin, 2010) dan Sembilan Asas Media Sosial (Pedoman Pemanfaatan Media Sosial Instansi Pemerintah oleh Menteri Pendayagunaan Aparatur Negara dan Reformasi Birokrasi (PAN-RB) RI (2013).

\section{Media Sosial Facebook}

Media Sosial yang dipilih dalam penelitian ini adalah Facebook sebagai platform media sosial urutan pertama paling banyak diakses masyarakat Indonesia, sebagaimana hasil publikasi survei Asosiasi Penyelenggara Jasa Internet Indonesia (APJII, 2017).

Facebook merupakan situs jejaring sosial yang dapat menghubungkan penggunanya dari berbagai belahan dunia melalui keterhubungan profil, berkirim pesan personal melalui inbox maupun melalui wall/news feed, chatting, bermain bersama, berbagi file dan photo, 
Jurnal Administrasi Negara

ISSN : 2598-4039 (Online)

ISSN : 2302-2231 (Print)
Dila Novita, Elvira Suryani, Amanda

Morlian, Mita Widyastuti, Fadhilah

Universitas Islam ' 45 promosi bisnis hingga bermain game online. Apabila Humas Pemerintah akan mempergunakan Facebook sebagai media relations dengan publiknya, Divisi Humas dapat memilih apakah akan mempergunakan akun regular (personal account), group ataukah berupa Page (Christine, 2009).

\section{Sosialisasi Pemilihan Umum 2019} melalui Facebook Komisi Pemilihan Umum Kota Bekasi

Sosialisasi merupakan aktivitas komunikasi yang bertujuan untuk menciptakan perubahan pengetahuan, sikap mental, dan perilaku khalayak sasaran terhadap ide pembaruan (inovasi) yang ditawarkan. Sosialisasi juga merupakan pengenalan dan penyebarluasan program kepada masyarakat dan aparat yang menjadi sasaran program serta kepada pihakpihak lain yang berkepentingan atau yang menjadi mitra kerja (Cahyani, 2019).

Berdasarkan Tugas dan Wewenang Komisi Pemilihan Umum Kabupaten/Kota dalam penyelenggaraaan Pemilu Anggota Dewan Perwakilan Rakyat, Dewan Perwakilan Daerah, dan Dewan Perwakilan rakyat Daerah poin $\mathrm{n}$ dan Tugas dan Wewenang KPU Kabupaten/Kota dalam penyelenggaraan Pemilu Presiden dan wakil Presiden poin $\mathrm{k}$ berisi tentang sosialisasi penyelenggaraan Pemilu/ atau yang berkaitan dengan tugas dan wewenang KPU Kabupaten/Kota kepada masyarakat.

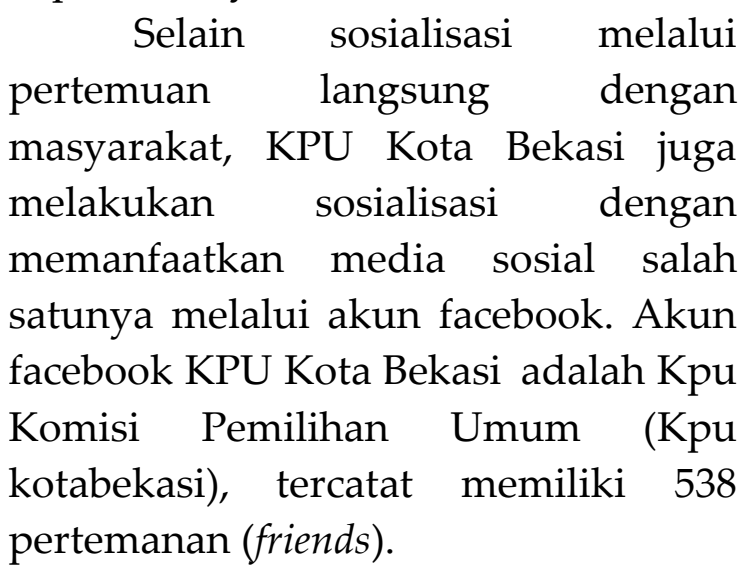

\section{METODE PENELITIAN}

Penelitian ini mengacu pada paradigma konstruktivisme dengan penerapan metode kualitatif dan desain penelitian Studi Kasus. Alasan menggunakan metode ini adalah karena peneliti mengkaji secara mendalam Kebijakan Komisi Pemilihan Umum Kota Bekasi terkait pemanfaatan media sosial dalam pengelolaan informasi di KPU dan bagaimana kebijakan itu diadaptasikan dalam membangun komunikasi kepada publik terkait informasi Pemilu 2019.

\section{Sumber dan Teknik Perolehan Data}

Pada penelitian ini, sumber data primer diperoleh melalui wawancara mendalam dengan 3(tiga) orang Komisioner KPU Kota Bekasi. Peneliti memilih 3(tiga) orang yang dipandang mengerti dan menguasai 
Jurnal Administrasi Negara

ISSN : 2598-4039 (Online)

ISSN : 2302-2231 (Print)
Dila Novita, Elvira Suryani, Amanda

Morlian, Mita Widyastuti, Fadhilah

Universitas Islam '45 permasalahan terkait dengan penelitian ini. Terdiri dari 1(satu) orang Ketua dan 2(dua) Anggota KPUD Kota Bekasi. Ketiga informan tersebut, peneliti anggap mampu merepresentasikan dan menggambarkan pokok permasalahan penelitian yang sedang dilakukan. Informan di atas diwawancarai dengan wawancara mendalam (in-depth interview) menggunakan Panduan Wawancara Mendalam. Wawancara kualitatif dilakukan oleh peneliti dengan maksud untuk mengetahui tentang realitas, makna-makna subyektif yang dipahami oleh individu yang terkait tersebut dan sesuai dengan topik yang diteliti.

\section{Wawancara Mendalam (in-depth interview)}

Komisioner KPU Kota Bekasi menjadi sumber utama data penelitian ini. Penelitian ini menggunakan teknik wawancara mendalam (indepthinterview) atau disebut dengan semistructured interview sebagai data primer. Patton (2002:341) mengemukakan bahwa wawancara kualitatif bertujuan untuk mengetahui apa yang ada dalam pikiran orang lain, kemudian menyusun cerita mereka dan menjawab permasalahan yang berkaitan dengan penelitian. Wawancara kualitatif dilakukan oleh peneliti dengan maksud untuk mengetahui tentang realitas maknamakna subyektif yang dipahami oleh individu yang sesuai dengan topik yang diteliti.

Tabel 1. Informan Penelitian

\begin{tabular}{|c|c|c|c|c|c|}
\hline Nama Informan & \multirow{2}{*}{\multicolumn{3}{|c|}{$\frac{\text { Jabatan }}{\text { Ketua KPU Kota Bekasi }}$}} & \multicolumn{2}{|l|}{ Divisi } \\
\hline 1. Nurul Sumarheni & & & & $\begin{array}{l}\text { Divisi Keuangar } \\
\text { Logistik, dan } \\
\text { Tangga }\end{array}$ & $\begin{array}{l}\text { Umum, } \\
\text { Rumah }\end{array}$ \\
\hline 2. Ali Syaefa & $\begin{array}{l}\text { Komisioner } \\
\text { Bekasi }\end{array}$ & KPU & Kota & $\begin{array}{l}\text { Divisi } \\
\text { Penyelenggaraan }\end{array}$ & Teknis \\
\hline 3. Yunita & $\begin{array}{l}\text { Komisioner } \\
\text { Bekasi }\end{array}$ & KPU & Kota & $\begin{array}{l}\text { Divisi } \\
\text { Pendidikan } \\
\text { Parmas, dan SDN }\end{array}$ & $\begin{array}{l}\text { osialisasi, } \\
\text { Pemilih, }\end{array}$ \\
\hline
\end{tabular}

\section{Studi Kepustakaan}

Penelitian ini juga memanfaatkan studi kepustakaan sebagai data sekunder. Studi pustaka merupakan data yang dikumpulkan dari tangan kedua atau sumber-sumber lain yang telah tersedia sebelum penelitian dilakukan. Studi kepustakaan, yaitu 
Jurnal Administrasi Negara

ISSN : 2598-4039 (Online)

ISSN : 2302-2231 (Print)
Dila Novita, Elvira Suryani, Amanda

Morlian, Mita Widyastuti, Fadhilah

Universitas Islam '45 cara untuk mengumpulkan data dengan menggunakan dan mempelajari literature buku-buku kepustakaan yang ada untuk mencari konsepsi-konsepsi dan teori-teori yang berhubungan erat dengan permasalahan. Studi kepustakaan bersumber pada jurnal, laporan-laporan, skripsi, tesis, disertasi, buku, surat kabar cetak maupun online, dan dokumen-dokumen lain yang berhubungan dengan permasalahan yang diteliti (Zed, 2004).

\section{HASIL DAN PEMBAHASAN}

Pemanfaatan Media Sosial untuk Kegiatan Kehumasan KPU Kota Bekasi

Komisi Pemilihan Umum memanfaatkan Facebook dan Instagram secara efektif sejak Pilkada 2018 sebagai media untuk menyampaikan informasiinformasi terkait Kepemiluan. Sebelumnya tahun 2014 media sosial juga sudah dimanfaatkan, namun belum optimal karena pengelolaan informasi pemilu dikelola oleh tim Media Center (MC). Tim MC ini tidak hanya mengelola media sosial KPU tetapi juga website dan berbagai bentuk-bentuk media komunikasi lainnya secara profesional.

Setelah tim MC ditiadakan pasca Pilkada, KPU Kota Bekasi membentuk tim khusus yang ditugaskan untuk mengelola media sosial. Postinganpostingan terkait dengan kegiatan pemilu ditugaskan ke beberapa staf untuk menangani. Selain itu, komisioner juga ikut secara teknis mengelola. Informasi yang disebarkan dalam bentuk e-flyer di facebook dan Instagram. Informasi lebih lengkap disajikan melalui website KPU, seperti peraturan-peraturan atau regulasi. Sementara kalau di facebook dan di Instagram, sifatnya informasi singkat dan instan atau link-link yang langsung diakseskan ke website KPU

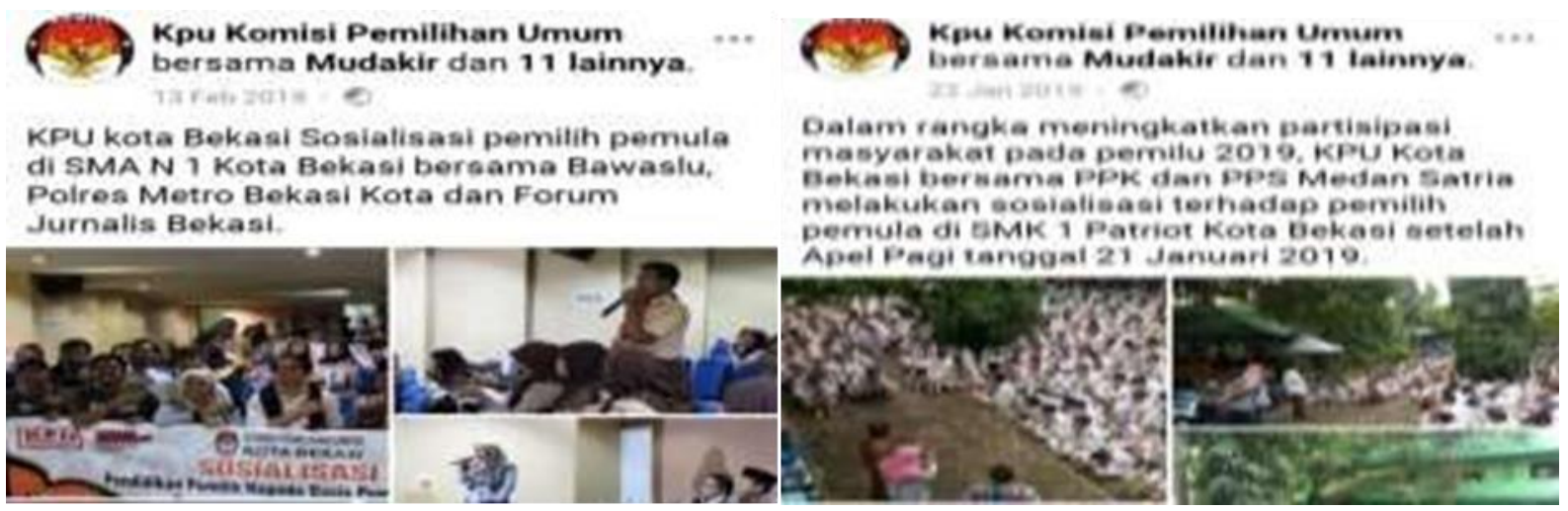

Gambar 1. Postingan Pada Akun Media Sosial KPU Kota Bekasi

Sumber: Media Sosial KPU Kota Bekasi

Evaluasi Komunikasi Publik Komisi Pemilihan Umum

Melalui Media Sosial Pada Pemilu Serentak 2019 
Jurnal Administrasi Negara

ISSN : 2598-4039 (Online)

ISSN : 2302-2231 (Print)
Dila Novita, Elvira Suryani, Amanda

Morlian, Mita Widyastuti, Fadhilah

Universitas Islam ‘ 45
Selain menggunakan akun media sosial KPU, masing-masing komisioner juga memanfaatkan akun pribadi media sosial masing-masing untuk memposting informasi tentang pemilu. Sekaligus juga memposting ulang informasi yang diposting di media sosial KPU pada akun medsos masingmasing komisioner, agar notifikasi dari informasi yang diposting bisa memicu netizen untuk menambah pertemanan dengan akun KPU.

Pemanfaatan Akun medsos institusi dimaksimalkan khususnya pada saat tahapan Pemilu. Informasi penting terus diupdate dan diulangulang agar masyarakat luas mengetahui dan terus mengingat apa yang disampaikan, seperti tentang tata cara pindah memilih, waktu pendaftaran pemilih, tahapan pemilihan, dan sebagainya.

Komisioner KPU mengakui bahwa tanggung jawab sebagai penyelenggara pemilu tidak selesai hanya pada saat pemilu dilaksanakan, tapi setelah Pemilu selesai pun, KPU juga memiliki kewajiban untuk melakukan Pendidikan politik ke masyarakat yang salah satunya bisa dilakukan melalui media sosial. Materi yang akan diposting disiapkan oleh komisioner, kemudian staf yang memposting di akun KPU. Terkait postingan di masing-masing akun pribadi komisioner hanya merepost apa yang sudah diposting di akun resmi KPU atau KPU RI.

Strategi KPU dalam memperkenalkan atau menyebar luaskan akun media sosial institusi tidak hanya melalui repost informasi di akun pribadi komisioner, namun juga melalui beberapa kegiatan dalam bentuk sayembara, kegiatan sosialisasi secara offline/ketika bertemu langsung dengan masyarakat, membuat lomba photo selfi yang latarnya kegiatan yang sedang diselenggarakan KPU, dan lainlain. Selain itu, keterlibatan badan adhock seperti Panitia Pemilihan Kecamatan (PPK) dan Panitia Pemungutan Suara (PPS) untuk ikut membantu menyosialisasikan akun resmi KPU ke masyarakat. Pada Pemilu 2019 lalu, KPU juga membentuk Relawan Demokrasi dan Agen Sosialisasi yang kemudian diminta berteman dengan akun media sosial KPU, selanjutnya tugas mereka merepost semua informasi yang diposting di akun media sosial KPU pada akun media sosial masing-masing.

Terkait dengan Implementasi Pedoman Pemanfaatan Media Sosial Instansi Pemerintah yang dirumuskan Kementerian Reformasi Birokrasi (KEMEN PAN/RB) terdapat Sembilan azas: Faktualitas; semua postingan di akun medsos KPU sesuai dengan fakta dan data misalnya terkait tahapan pemilu, pengumuman perekrutan badan adhoc, informasi persyaratan, dan 
Jurnal Administrasi Negara

ISSN : 2598-4039 (Online)

ISSN : 2302-2231 (Print)
Dila Novita, Elvira Suryani, Amanda

Morlian, Mita Widyastuti, Fadhilah

Universitas Islam ‘ 45 hasil seleksi, dan sebagainya. Semua informasi tersebut disimpan dalam format PDF sebelum diposting. Semua informasi yang diposting ditujukan untuk publik dan tidak dibatasi hanya untuk publik tertentu saja, jadi siapapun bisa mengakses dan melihat informasi yang disajikan, tanpa ada keyword tertentu.

Nama akun media sosial facebook maupun instagram KPU Kota Bekasi sangat mudah dikenal dan diingat, karena langsung mencantumkan nama resmi institusi (Kpu Kota Bekasi). Namun sayangnya akun KPU Kota Bekasi ternyata ditemukan ada 2(dua) sehingga bagi orang yang tidak tahu, kemudian mau mengakses akun tersebut, bisa mengalami kebingungan. Terjadinya dobel akun tersebut ternyata karena akun Facebook KPU Periode sebelumnya (2013-2018) tidak ditutup, karena pengelola sebelumnya tidak diketahui, sehingga komisioner yang baru tidak memiliki akses dengan akun tersebut. Situasi tersebut membuat komisioner yang baru memutuskan untuk membuat akun Facebook KPU yang lain. Sehingga jika publik ingin mencari akun facebook KPU Kota Bekasi, akan ditemukan 2(dua) akun berbeda. Ciri khas dari akun facebook yang baru adalah tampilan semua photo komisioner KPU periode saat ini (20192024). Setidaknya photo profil tersebut yang mempermudah publik untuk mengetahui akun resmi KPU Kota Bekasi terbaru.

Namun sayangnya akun facebook yang baru ini juga memiliki masalah. Akun ini dibuat oleh Tim Media Center pada saat Pemilihan Kepala Daerah Kota Bekasi tahun 2018. Setelah Pilkada selesai, Tim Media Center ini dibubarkan karena tidak ada alokasi anggaran lagi dari Pemerintah Kota Bekasi untuk pengelolaan Media Center Pasca Pilkada. Sehingga akun Facebook tersebut diambilalih oleh staf KPU dan satu orang komisioner yang ditunjuk untuk mengelola. Namun, karena yang membuat akun adalah orang lain yang tidak lagi bekerja di KPU, menyebabkan akun tersebut hanya bisa diakses oleh salah satu komisioner tersebut tanpa bisa diperbaharui kembali username dan passwordnya karena menggunakan email orang yang membuat. Jadi jika komisioner yang ditunjuk ini perangkat handphonenya rusak atau hilang atau $\log$ out, maka akun facebook KPU tidak bisa diakses lagi oleh semua semua staf atau komisioner KPU saat ini. Salah satu rencana solusi dari persoalan ini adalah KPU Kota Bekasi akan menutup akun yang lama dan membuat akun baru yang resmi.

Kendala lain yang dihadapi komisioner dalam pengelolaan akun facebook KPU ini adalah tidak ada Sumber Daya Manusia khusus yang dibayar untuk mengelola. Sehingga 
Jurnal Administrasi Negara

ISSN : 2598-4039 (Online)

ISSN : 2302-2231 (Print)
Dila Novita, Elvira Suryani, Amanda

Morlian, Mita Widyastuti, Fadhilah

Universitas Islam '45 kalau ada pertanyaan atau komen dari netizen terkait postingan KPU, maka tidak ada yang merespon atau menanggapi atau menjawab pertanyaan netizen. Sedangkan, terkait pertanyaan yang diajukan melalui email, biasanya Ketua KPU sendiri ikut menjawab, karena email KPU tersebut sudah ter $\log$ in di perangkat handphone Ketua KPU. Jika ada pertanyaan via email tentang data, biasanya akan diteruskan ke bagian kesekretariatan atau Kasubbag terkait untuk menjawab (wawancara dengan Nurul Sumarheni, 2020).

Pemanfaatan Media Sosial Komisi Pemilihan Umum Kota Bekasi Sesuai Azas Media Sosial

Penelitian ini juga membahas bagaimana Azas Media Sosial yang tercantum dalam Pedoman Pemanfaatan Media Sosial Instansi Pemerintah oleh Menteri Pendayagunaan Aparatur Negara dan Reformasi Birokrasi (2013) diimplementasikan.

Untuk azas Interaktifitas; berfokus sejauhmana komunikasi yang dilakukan melalui facebook KPU berjalan secara interaktif dan multiarah. Ketua KPU Kota Bekasi, Nurul Sumarheni mengakui bahwa azas interaktifitas ini belum berjalan secara optimal karena jumlah pertemanan dengan netizen masih sedikit, masih kurang dari 1000 orang. Untuk itu fanpage bisa dipertimbangkan agar netizen mengetahui bahwa akun tersebut adalah resmi dibuat oleh KPU Kota Bekasi.

$$
\text { Selanjutnya tentang azas }
$$

Harmonisasi berhubungan dengan upaya KPU dalam menciptakan hubungan sinergis, saling menghargai dengan berbagai pihak melalui media sosial KPU. Ketua KPU menjelaskan tentang upaya preventif yang dilakukan dengan menghindari membuat postingan-postingan yang memihak, tidak melakukan analisa terkait pihakpihak tertentu melalui postingan. Jadi informasi yang disampaikan sifatnya normatif saja, tidak memihak atau mengarah kepada pihak-pihak tertentu, sifatnya netral saja dan sesuai dengan Tugas Pokok dan Fungsi KPU. Postingan facebook KPU selama ini juga menjunjung azas Etis, dengan menerapkan perilaku sopan sesuai dengan etika atau kode etik yang ditetapkan di media sosial. KPU Kota Bekasi juga menghindari postingan yang sifatnya sensasional dan kontroversial, jadi hanya fokus pada penyampaian informasi saja. Itu lah yang dilakukan KPU untuk menjaga Harmonisasi melalui media sosial KPU.

Pada Azas Kesetaraan terkait dengan sejauhmana komisioner membina hubungan baik dengan pemangku kepentingan yang lain, terutama dengan pemerintah daerah. Komisioner menganggap bahwa komunikasi sebagai faktor yang paling 
Jurnal Administrasi Negara

ISSN : 2598-4039 (Online)

ISSN : 2302-2231 (Print)
Dila Novita, Elvira Suryani, Amanda

Morlian, Mita Widyastuti, Fadhilah

Universitas Islam '45 utama, karena menyadari bahwa komunikasi yang baik dengan berbagai pihak baik pemerintah daerah, Kepolisian, TNI dan berbagai pemangku kepentingan lainnya akan berdampak positif pada kesuksesan penyelenggaraan pemilu di Kota Bekasi. Jadi walaupun Pemilu sudah selesai, komunikasi terus dijalin oleh komisioner dengan berbagai pihak tersebut. Salah satunya dengan membuat group di WhatsApp.

Azas Profesionalisme terkait dengan bagaimana Facebook KPU dikelola berdasarkan keahlian, keterampilan dan pengalaman. Untuk hal ini komisioner KPU mengakui bahwa azas ini belum sepenuhnya dijalankan. Namun hal tersebut ke depannya akan diperbaiki. Salah satu yang akan diupayakan dengan meminta Tenaga Harian Lepas (TKK) dari Pemerintah Kota yang memiliki keahlian khusus di bidang Information Technology (IT) atau pengelolaan media sosial. Sehubungan staf yang ada di KPU sudah memiliki beban kerja masing-masing pada saat ini. Diharapkan tenaga khusus ini nantinya bisa mengelola fanpage media sosial KPU, sehingga bisa menambah lebih banyak pertemanan dan informasi yang terkait dengan Pemilu atau KPU lebih tersebar ke publik. Pengelolaan akun Media Sosial KPU juga harus dilakukan jauh-jauh hari, tidak hanya pada saat akan masuk tahapan Pemilu.

\section{Terkait dengan}

Azas Akuntabilitas membahas tentang sejauhmana media sosial dimanfaatkan secara bertanggung jawab. Sejauh ini media sosial dikelola secara normatif saja, jadi tidak terlalu ada masalah. Semua postingan bersifat resmi dari institusi sehingga isi dan sumber informasi akuntabel. Hal tersebut tentu saja menumbuhkan kepercayaan publik pada informasi yang diposting.

Komisioner KPU Kota Bekasi mengakui pengelolaan Media Sosial KPU khususnya Facebook masih kurang optimal karena masih ada keterbatasan Pemahaman Dalam Pengelolaan Media Sosial, Keterbatasan Sumber Daya Pengelola, dan Keterbatasan Alokasi Anggaran untuk pengelolaan. Selanjutnya KPU Kota Bekasi mengharapkan perbaikan pengelolaan media sosial juga didukung oleh KPU RI misalnya melalui penganggaran secara lebih serius dan fokus meskipun, sedang tidak dalam tahapan pemilu. Bagi KPU yang sedang tidak dalam persiapan menjelang pemilu atau pilkada juga seharusnya tetap diberikan anggaran pengelolaan media sosial dan website. Selama ini anggaran pengelolaan website dinilai sangat kecil. Bahkan, pengelolaan website selama ini tidak dianggarkan di APBN, jadi KPU menerima hibah dari Pemerintah Daerah Kota Bekasi melalui APBD sejumlah 10 juta setahun. Namun itu pun tidak seterusnya dianggarkan, 
Jurnal Administrasi Negara

ISSN : 2598-4039 (Online)

ISSN : 2302-2231 (Print)
Dila Novita, Elvira Suryani, Amanda

Morlian, Mita Widyastuti, Fadhilah

Universitas Islam '45 karena jika tidak sedang dalam tahapan Pilkada, maka hibah tersebut bisa dihentikan.

Ketua KPU Kota Bekasi, Nurul Sumarheni menilai, antara Kebijakan tentang Pemanfaatan Media Sosial untuk instansi publik dengan alokasi anggaran tidak seiring. Alokasi anggaran untuk Pemilu 2019 lalu lebih banyak untuk logistik, jadi hal lain kurang diperhatikan, termasuk pengelolaan media sosial KPU.

Berdasarkan studi pustaka yang peneliti lakukan melalui pencarian publikasi hasil penelitian dalam bentuk artikel jurnal, skripsi atau tesis, tidak banyak ditemukan penelitian yang membahas tentang pemanfaatan media sosial oleh Komisi Pemilihan Umum Pada Pemilu Serentak 2019. Penelitian terdahulu lebih banyak membahas tentang Strategi Sosialisasi dan Komunikasi KPU dalam meningkatkan partisipasi pemilih pada pemilu serentak 2019 (Pulungan dkk, 2020; Novita \& Ai, 2020).

Sedangkan penelitian lain lebih fokus pada Peningkatan Partisipasi Pemilih dalam Pemilihan Kepala Daerah (Yusuf, 2020), Strategi Pemenangan Artis dalam Pemilihan Umum Legislatif (Fadhli, 2014); Strategi Komunikasi Politik Perempuan Dalam Meraih Kepemimpinan Daerah (Hubeis, 2019); Strategi Komunikasi Partai Politik Dalam Meningkatkan Partisipasi Pemilih Pemula (Aditya, 2020).
Di sisi lain, peneliti juga hanya mendapatkan beberapa referensi terkait pemanfaatan Media Sosial baik oleh Partai Politik maupun Komisi Pemilihan Umum selama penyelenggaraan Pemilihan Umum (Furqon, 2013; Budifebrianto, 2020). Penelitian lain ada juga yang membahas tentang pemanfaatan media sosial oleh instansi publik seperti Kepolisian (Putri, 2019); DPRD (Hikmat, 2018) sebagai upaya meningkatkan citra institusi-institusi tersebut di mata publik.

Sedikitnya hasil penelitian yang membahas permasalahan sebagaimana yang diangkat dalam penelitian ini menunjukkan bahwa penelitian ini merupakan sumber referensi yang berharga sebagai upaya menambah khazanah keilmuan terkait penyelenggaraan pemilihan umum 2019 dan pemanfaatan media sosial sebagai upaya membangun alternatif strategi komunikasi kepada publik.

Terkait dengan teori yang menjadi acuan dalam penelitian sebelumnya misalnya diambil dari teori tentang Determinisme Teknologi oleh Marshal McLuhan (1962), Teori Komunikasi Dunia Maya oleh Burhan Bungin (2006), Teori Uses and Gratification oleh Elihu Katz (1970), dan Teori Strategi Komunikasi oleh Rogers (1982). Sedangkan penelitian ini berfokus pada teori Pemanfaatan Media Sosial untuk Kegiatan Kehumasan (Jin, 2010) dan Sembilan Asas Media Sosial 
Jurnal Administrasi Negara

ISSN : 2598-4039 (Online)

ISSN : 2302-2231 (Print)
Dila Novita, Elvira Suryani, Amanda

Morlian, Mita Widyastuti, Fadhilah

Universitas Islam ‘45
(Pedoman Pemanfaatan Media Sosial Instansi Pemerintah oleh Menteri Pendayagunaan Aparatur Negara dan Reformasi Birokrasi (PAN-RB) RI (2013). Dari kesembilan azas tersebut, diakui oleh komisioner KPU bahwa Azas yang belum optimal diimplementasikan adalah Profesionalisme karena pengelolaan media sosial KPU belum ditangani oleh unit khusus dan pengelola saat ini bukan orang yang memahami tentang pengelolaan media sosial, khususnya untuk instansi publik.

Berdasarkan rujukan teori dan Peraturan Menteri tersebut diketahui bahwa KPU Kota Bekasi memanfaatkan platform media sosial Facebook dan Instagram, ditambah dengan Website dan Chat Group melalui WhatsApp, namun akun sosial media tersebut belum dikelola dengan maksimal. Indikasinya, media sosial tersebut baru secara serius dimanfaatkan hanya ketika memasuki persiapan tahapan pemilu, belum ada satu unit khusus yang ditugaskan untuk mengelola media sosial tersebut. Sehingga belum ada upaya strategis untuk meningkatkan jumlah pertemanan, menjawab komentar para netizen yang merespon setiap postingan KPU Kota Bekasi, komunikasi yang terjadi sifatnya hanya satu arah, tidak terjadi interaksi lebih lanjut yang semestinya dimanfaatakan komisioner atau staf pengelola akun media sosial tersebut.
Temuan penting lainnya, meskipun sudah ada Peraturan Permenpan RB tentang pedoman pemanfaatan media sosial instansi pemerintah, namun di sisi lain belum ada anggaran khusus yang dialokasikan untuk mengelola media sosial baik melalui penganggaran APBN maupun APBD. Sehingga pengelolaan media tersebut menjelang Pemilu sifatnya hanya sporadis dan pelengkap dari bentuk sosialisasi lain yang memanfaatkan media komunikasi konvensional seperti tatap muka, baliho, poster, dll. Media Konvensional sebenarnya justru lebih banyak menghabiskan jumlah anggaran dibandingkan dengan mengoptimalkan media sosial sebagai media baru yang paling banyak diakses oleh netizen. Media sosial digunakan oleh berbagai kalangan dan berbagai tingkatan usia, terutama generasi milenial yang pada pemilu 2019 lalu di Kota Bekasi berjumlah sekitar 39\% dari jumlah pemilih secara keseluruhan (Novita \& Ai, 2020).

\section{PENUTUP}

Komisi Pemilihan Umum Kota Bekasi sudah memanfaatkan Media Sosial Facebook sebagai salah satu strategi membangun komunikasi kepada netizen, namun belum dilakukan secara optimal. Hal tersebut terjadi karena keterbatasan dalam Pengetahuan Dalam Mengelola Media 
Jurnal Administrasi Negara

ISSN : 2598-4039 (Online)

ISSN : 2302-2231 (Print)
Dila Novita, Elvira Suryani, Amanda

Morlian, Mita Widyastuti, Fadhilah

Universitas Islam '45
Sosial, keterbatasan Sumber Daya Manusia, dan keterbatasan Sumber Anggaran yang dialokasikan baik oleh Pemerintah Pusat melalui KPU RI maupun Pemerintah Daerah Kota Bekasi. Fakta tersebut mengindikasikan bahwa media sosial belum dianggap sebagai media komunikasi yang strategis untuk dimanfaatkan selama Pemilihan Umum 2019 di Kota Bekasi. Rekomendasi untuk pemilihan umum atau pemilihan kepala daerah berikutnya, KPU Kota Bekasi diharapkan lebih optimal dalam memanfaatkan media sosial agar komunikasi yang dilakukan lebih efisien dan efektif sehingga bisa menjangkau semua lapisan masyarakat khususnya netizen di Kota Bekasi sebagai pengguna aktif media sosial.

\section{REFERENSI}

Aditya, A. (2020). Analisis Strategi Komunikasi Partai Politik Baru

Dalam Meningkatkan Partisipasi Politik Pemilih Pemula (Studi kasus DPD Partai Solidaritas Indonesia Kota Parepare). Jurnal Al-Bayan: Media Kajian dan Pengembangan Ilmu Dakwah, 26(1), 43-76.

Ansori, L. (2017). Telaah terhadap Presidential Threshold dalam Pemilu Serentak 2019. Jurnal Yuridis, 4(1), 15-27.

APJII. (2017). Penetrasi dan Perilaku Pengguna Internet Indonesia. Hasil Survei Asosiasi Penyelenggara Jasa Internet Indonesia. https://apjii.or.id/ (diakses, 28 Juni 2019).

Asy'ari, S., Hilipito, M. R., \& Ali, M. M. (2013). Model dan Implementasi Putusan Mahkamah Konstitusi dalam Pengujian UndangUndang (Studi Putusan Tahun 2003-2012). Jurnal Konstitusi, 10(4), 675-708.

Budifebrianto, R., \& Delliana, S. (2020).

Strategi Kampanye Komisi Pemilihan Umum (KPU) dalam Meningkatkan Pemilih Aktif Pada Pemilu 2019 (Kajian Deskriptif di Akun Instagram KPU). Restorica: Jurnal Ilmiah Ilmu Administrasi Negara dan Ilmu Komunikasi, 6(2), 1-11. 
Jurnal Administrasi Negara

ISSN : 2598-4039 (Online)

ISSN : 2302-2231 (Print)
Dila Novita, Elvira Suryani, Amanda

Morlian, Mita Widyastuti, Fadhilah

Universitas Islam '45
Cahyani, Adelia Masrifah. (2019). Strategi Komunikasi Humas Pemerintah Kota Surabaya Melalui Media Sosial. Undergraduate thesis, Surabaya. UIN Sunan Ampel.

Chaykowski, Kathleen (2016), Meet The Queen Of Imgur, The ImageSharing Site That's Half The Size Of Twitter, http://www.forbes.com/sites/kat hleenchaykowski/2016/01/08/me et-the- queen-of-imgur-theimage-sharing-site-thats-halfthe-size-oftwitter/\#2715e4857a0b53da76c46 cd0, Access Date: 8 August 2019

Deighton, J. \& Kornfeld, L. (2009). Interactivity's Unanticipated Consequences for Marketers and Marketing. Journal of Interactive Marketing, 23(1), 4-10.

Fadhli, M. R. Strategi kemenangan artis dalam pemilihan umum legislatif 2014 (studi tentang lucky hakim dan kemenangannya Di Dapil Jawa Barat Vi Kota Depok dan Kota Bekasi) (Bachelor's thesis, Jakarta: Fakultas Ilmu Ilmu Sosial dan Ilmu Politik UIN Syarif Hidayatullah). Fadhli, M. R. Strategi kemenangan artis dalam pemilihan umum legislatif 2014 (studi tentang lucky hakim dan kemenangannya Di Dapil Jawa Barat Vi Kota Depok dan Kota Bekasi) (Bachelor's thesis,
Jakarta: Fakultas Ilmu Ilmu Sosial dan Ilmu Politik UIN Syarif Hidayatullah).

Furqon, A. (2013). Strategi Komunikasi Politik Partai Keadilan Sejahtera (PKS) Secara Ekspresi Simbolik di Media Sosial Jelang Pemilu 2014.

Gallagher, Christine. “Create Visibility For Your Business on Facebook: Top Ten Ways." Articlesbase. 1 April 2009. http://www.articlesbase.com/soc ial-marketing- articles/createvisibility-for-your-business-onfacebook-top-ten-ways845996.html (accessed Juni 23, 2019).

Gamayanto, I., \& Nilawati, F. E. (2017). Pengembangan dan implementasi dari wise netizen (e-comment) di Indonesia. techno. com, 16(1), 80-95.

Genc, Merve \& Burcu Oksuz. (2015). A Fact or An Illution: Effective Social Media Usage of Female Enterpreneurs. Elsevier Journal. Procedia Social and Behavioral Sciences, 195, 293- 300.

Hikmat, M. (2018). Strategi

Pemanfaatan Media Sosial

Untuk Meningkatkan Citra Positif Dprd Dalam Persepsi Rakyat Daerah. Jurnal Common, 2(1).

Jones, Ron. "Social Media Marketing 101, Part 1." Search Engine 
Jurnal Administrasi Negara ISSN : 2598-4039 (Online) ISSN : 2302-2231 (Print)
Dila Novita, Elvira Suryani, Amanda Morlian, Mita Widyastuti, Fadhilah

Universitas Islam ' 45
Watch. 29 Februari 2009. http://sbinfocanada.about.com/g i/o.htm?zi=1/XJ\&zTi=1\&sdn=sbi nfocanada\&cd $\mathrm{n}=$ money $\& \mathrm{tm}=22 \& \mathrm{f}=00 \& \mathrm{tt}=8 \& \mathrm{bt}$ $=9 \& \mathrm{bts}=83 \& \mathrm{zu}=\mathrm{http} \% 3 \mathrm{~A} / / \mathrm{search}$ enginewatch.com $/ 36328$ 09 (accessed August 4, 2019).

Meredith, M. J. (2012). Strategic communication and social media: An MBA course from a business communication perspective. Business and Professional Communication Quarterly, 75( 1), 89-95.

Miller, R. \& Lammas, N. (2010). Social media and its implications for viral marketing. Asia Pacific Public Relations Journal, 1-9.

Negara, M. P. A. Peraturan Menteri Pendayagunaan Aparatur Negara dan Reformasi Birokrasi Republik Indonesia Nomor 83 Tahun 2012 Tentang Pedoman Pemanfaatan Media Sosial Instansi Pemerintah 1 (2013).

Novita, D \& Fitri, A. (2020). PENINGKATAN PARTISIPASI PEMILIH MILENIAL: STRATEGI KOMUNIKASI DAN SOSIALISASI KOMISI PEMILIHAN UMUM PADA PEMILU 2019. Makna: Jurnal Kajian Komunikasi, Bahasa, dan Budaya, 7(2), 56-84.

DOI: $\underline{\text { https://doi.org/10.33558/m }}$ akna.v7i2.2182
Osatuyi, B. (2013). Information sharing on social media sites. Computers in Human Behavior, 29, 26222631.

P. K. P. U. (2019). Tahun 2018 tentang Perubahan atas Peraturan Komisi Pemilihan Umum Nomor 7 Tahun 2017 tentang Tahapan. Program, dan Jadwal Penyelenggaraan Pemilihan Umum Tahun.

Papasolomou, I. \& Melanthiou, Y. (2012). Social media: Marketing public relations' new best friend. Journal of Promotion Management, 18 (3), 319-328.

Peters, K., Chen, Y., Kaplan, A. M., Ognibeni, B., \& Pauwels, K. (2013). Social media metrics A framework and guidelines for managing social media. Journal of Interactive Marketing, 27, 281298.

Prasetyoningsih, N. (2014). Dampak Pemilihan Umum serentak bagi pembangunan demokrasi Indonesia. Media Hukum, 21(2), 23.

Pribadi, A. S., Pratiwi, M. M. S., \& Brotowidagdo, R. (2019). Motif Afiliasi Pengguna Aktif Facebook. Proyeksi: Jurnal Psikologi, 6(2), 50-57.

Pulungan, M. C., Rahmatunnisa, M., \& Herdiansah, A. G. (2020). Strategi Komisi Pemilihan Umum Kota Bekasi Dalam 
Jurnal Administrasi Negara

ISSN : 2598-4039 (Online)

ISSN : 2302-2231 (Print)
Dila Novita, Elvira Suryani, Amanda

Morlian, Mita Widyastuti, Fadhilah

Universitas Islam '45
Meningkatkan Partisipasi

Pemilih Pada Pemilu Serentak

Tahun 2019. Politea: Jurnal Politik Islam, 3(2), 251-272.Nuryanti, S. (2016). Menyiapkan Tata Kelola Pemilu Serentak 2019. Jurnal Penelitian Politik, 12(1), 14.

Putri, A. H. (2019). Strategi Pemberitaan Melalui Media Sosial Instagram Mengenai Citra KepolisiaN (Studi Kasus pada Humas Polres Metro Bekasi Kota) (Doctoral dissertation, Fisip Unpas).

Rahman, A. A., Amin, H. M. J., Si, M., Utomo, H. S., \& Si, M. (2017). Tugas dan Wewenang Komisi Pemilihan Umum Dalam Pemilihan Anggota Legislatif Kota Balikpapan Periode 20142019. E-journal Ilmu Pemerintahan, 5, 1232-1242.

Schreck,T. \& Keim, D. (2013). Visual analysis of social media data. Computer, 46(5), 68- 75.

Setiadi, A. (2016). Pemanfaatan Media Sosial untuk Efektifitas Komunikasi. Cakrawala- Jurnal Humaniora, 16(2).

Simamora, J. (2014). Menyongsong rezim pemilu serentak. Jurnal Rechtsvinding, 3(1), 21.

Solikhin, A. (2017). Menimbang Pentingnya Desentralisasi Partai Politik di Indonesia. Journal of Governance, 2(1).

Warisyah, Y. (2019, June). Pentingnya "pendampingan dialogis" orang tua dalam penggunaan gadget pada anak usia dini. In Seminar Nasional Pendidikan 2015 (pp. 130-138).

Yusuf, M. (2020). Strategi Komunikasi Komisi Pemilihan Umum (KPU) Kota Pekanbaru dalam Mensosialisasikan Pemilihan Umum 2019 (Doctoral dissertation, Universitas Islam Negeri Sultan Syarif Kasim Riau).

Zed, M. (2004). Metode Penelitian Kepustakaan. Jakarta: Yayasan Obor Indonesia 